\title{
Hubungan Pola Asuh Terhadap Perkembangan Anak Usia Dini
}

\section{G A A Sri Asri*}

Jurusan Pendidikan Guru Sekolah Dasar (PGSD), Universitas Pendidikan Ganesha, Singaraja, Indonesia.

\author{
A R T I C L E I N F O \\ Article history: \\ Received 20 Desember \\ 2017 \\ Received in revised form \\ 6 januari 2018 \\ Accepted 19 Januari 2018 \\ Available online 20 \\ Februari 2018 \\ Kata Kunci: \\ Otoriter, Demokratis, \\ Permisif, Nilai Agama \\ Moral, Sosial Emosional, \\ Bahasa, Kognitif, Fisik \\ Motorik \\ Keywords: \\ Authoritarian, Democratic, \\ Permissive, Religious Values \\ Moral, Social, Emotional, \\ Language, Cognitive, \\ Physical Motor
}

\begin{abstract}
A B S T R A K
Tujuan dari penelitian ini adalah untuk mengetahui apakah pola asuh otoriter, demokratis dan permisif secara bersama-sama menunjukkan adanya hubungan dengan perkembangan nilai moral agama, sosial emosional, bahasa, kognitif dan fisik motorik. Penelitian ini dilakukan di TK Kuntala Dewi III Desa Abiansemal, Kecamatan Abiansemal Badung, dengan sampel sebanyak 42 siswa yang ada pada TK Kuntala Dewi III. Hipotesis yang diajukan dalam penelitian hanya hipotesis utama tidak merinci lebih jauh pada bagian-bagian yang lebih kecil. Adapun hipotesis yang diajukan adalah terdapat hubungan secara bersama-sama antara pola asuh demokratis, otoriter, permisif dengan perkembangan nilai moral dan agama, perkembangan sosial emosional, perkembangan bahasa, perkembangan kognitif, perkembangan fisik. Analisis data penelitian menggunakan teknik korelasi kanonikal. Pengolahan data korelasi kanonikal dalam penelitian ini menggunakan bantuan program SPSS-16 for windows. Berdasarkan hasil anilisis data, dapat disimpulkan dua variabel dependen dan variabel independen memiliki hubungan yang signifikan. Dengan perkataan lain terdapat hubungan positif antara pola asuh otoriter, demokratis, dan permsisif dengan perkembangan nilai moral, sosial emosional, bahasa, kognitif, dan fisik motorik jika dilakukan pengujian secara kelompok. Dari tiga variabel independen, ada satu variabel yang memiliki hubungan yang sangat tinggi yaitu pola asuh demokratis. Dengan demikian dapat diartikan pola asuh demokratis berpengaruh positif terhadap perkembangan moral agama, soasial emosional, bahasa, kognitif, dan fisik motorik
\end{abstract}

\section{A B S T R A C T}

The purpose of this study was to determine whether the authoritarian parenting, democratic and permissive together suggest a link with the development of moral values of religious, social, emotional, language, cognitive and physical motor. This research was conducted in kindergarten Kuntala Dewi III, Abiansemal Village, District Abiansemal Badung, with a sample of 42 students that exist in kindergarten Kuntala Dewi III. The hypothesis of the study is only the main hypothesis gave no further details on the portions smaller. Research data analysis using canonical correlation techniques. Data processing canonical correlation in this study using SPSS 16 for windows. Based on the analysis of data it was inferred that the dependent variable and independent variables have a significant relationship. In other words, there is a relationship between the authoritarian parenting, democratic, and permsisif with the development of moral values, social, emotional, language, cognitive, physical and motor if the testing is done in groups. Of the three independent variables, there is one variable that have a very high that a democratic upbringing. Thus it can be interpreted democratic parenting influence on the moral development of religion, soasial emotional, language, cognitive, physical and motor. 


\section{Pendahuluan}

Keluarga merupakan wadah pendidikan yang sangat besar pengaruhnya dalam perkembangan sosial anak, oleh karena itu pendidikan anak tidak dapat dipisahkan dari keluarganya karena keluarga merupakan tempat pertama kali anak menyatakan diri sebagai mahkluk social dalam berinteraksi dengan kelompoknya(Mustakin 2013). Anak adalah peniru yang baik, mereka akan mereplikasi apapun yang mereka lihat, dengar, rasakan, dan alami (Yuniartiningtyas, 2012). Jika orang tua dan guru memperlakukan mereka dengan keras, maka anak akan tercetak berkepribadian keras dan kemungkinan besar mereka akan mempraktikannya dalam situasi bullying. Anak merupakan pribadi yang unik, dalam perkembangannya memerlukan perhatian yang khusus untuk optimalisasi serta tumbuh kembang anak. Menurut Sugiyanto (2015) Anak merupakan individu yang sedang berkembang di mana mereka sangat memerlukan perhatian khusus dari orang tuanya. Menurut Shanker, Blair \& Diamond (2008) ada beberapa faktor yang mempengaruhi pertumbuhan dan perkembangan anak, diantaranya: (1) environmental factors, (rumah, pekerjaan, penghasilan); (2) biological factors, (jenis kelamin, kesehatan); (3) interpersonal relationships (kedekatan, pola asuh); (4) early environments and experiences (pengalaman dan lingkungan sebelumnya).

Interpersonal relationships atau pola asuh merupakan salah satu faktor yang mempengaruhi pertumbuhan dan perkembangan anak. (Fatimah, 2012)Perkembangan anak sangat dipengaruhi oleh agen sosialnya. Hal yang paling utama dalam proses perkembangan sosial adalah keluarga yaitu orang tua dan saudara kandung. Kualitas hubungan orang tua dengan anak sangatlah penting dan berpengaruh terhadap perkembangan anak seperti kesehatan mental, gaya hidup, konsumsi rokok dan alkohol, kelahiran, cedera, kesehatan fisik, keterampilan sosial, dan pencapaian hidup (Simkis, dkk, 2013). Kualitas hubungan antara anak dengan orang tua tercermin lewat pola asuh. Pola asuh merupakan interaksi antara orang tua dengan anak yang mendidik, membimbing, dan mendisiplinkan anak menuju kedewasaan berdasarkan norma-norma yang ada di masyarakat (Edward, 2006). Hal ini berarti interaksi antara orang tua atau dengan lingkungan sekitarya mampu menstimulisasi perkembangan anak. Interaksi yang positif antara orang tua dengan anak akan membangun sebuah persepsi, mampu membimbing serta mengendalikan perilaku-perilaku negatif yang muncul pada anak serta mampu meningkatkan kemampuan dan keterampilan yang ada pada anak (Andrade, 2005). Apriastuti (2013) Orang tua merupakan pengambil peran utama dalam mengasuh anak - anaknya. Optimalisasi perkembangan anak dalam kehidupan bermasyarakat itu akan bergantung bagaimana dengan orang-orang di sekitar lingkungan mereka berada, lebih-lebih kedua orang tuanya (Israfil, 2015). Menurut (Santosa, 2013) Orangtua juga perlu untuk melakukan penyesuaian perilaku mereka terhadap anak, yang didasarkan atas kedewasaan perkembangan anak karena setiap anak memiliki kebutuhan dan mempunyai kemampuan yang berbeda-beda.

Sri Nur Solikah (2016) Pertumbuhan berhubungan dengan aspek fisik sedangkan perkembangan berhubungan dengan segala aspek yang berhubungan dengan segala perubahan yang terjadi pada anak baik perubahan fi sik, kogni f, emosi maupun psikososial. Pada masa balita terjadi pertumbuhan dan perkembangan yang sangat cepat. Pada masa ini anak memerlukan perhalan, kasih sayang dan arahan dari orang tuanya. Salah satu aspek terpen ng pada proses tumbuh kembang balita adalah perkembangan motorik.

Usia lima tahun pertama pada anak merupakan masa golden age pertumbuhan dan perkembangan anak. Pada masa ini terjadi perkembangan kemampuan dasar anak usia dini yang meliputi bidang pengembangan fisik/motorik, kognitif, sosial-emosional. Menurut Sulistyaningrum, Yeni (2011) usia 0 - 5 tahun merupakan masa keemasan sekaligus masa kritis dalam tahapan kehidupan manusia yang akan menentukan perkembangan anak selanjutnya. Hubungan yang baik antara anak dan orang tua akan membantu pembinaan kepribadian anak.

Empat perkembangan dasar ini memiliki makna yang sangat signifikan sebagai fondasi awal perkembangan anak menuju tahapan perkembangan selanjutnya. Perkembangan fisik/motorik meliputi empat aspek pengembangan, yaitu: (1) mengembangkan sistem saraf di otak, yang mempengaruhi kecerdasan dan emosi di otak; (2) mengembangkan otot-otot, yang memperngaruhi perkembangan kekuatan dan perkembangan motorik; (3) kelenjar endokrin, yang menyebabkan munculnya pola-pola tingkah laku baru; (4) Struktur tubuh/fisik,meliputi tinggi,berat dan proporsi.

Keluhan utama dari orangtua berupa kekhawatiran terhadap tumbuh kembang anak dapat mengarah kepada kecurigaan adanya gangguan tumbuh kembang, misalnya anaknya lebih pendek dari teman sebayanya, kepala kelihatan besar, umur 6 bulan belum bisa tengkurap, umur 8 bulan belum bisa duduk, umur 15 bulan belum bisa berdiri, 2 tahun belum bisa bicara dan lain lain. 
Perkembangan bahasa meliputi kemampuan menyimak, berbicara, membaca dan menulis. Perkembangan kognitif meliputi proses yang terjadi secara internal di dalam susunan syaraf pada saat manusia berpikir. Kemampuan kognitif ini akan berkembang secara bertahap sejalan dengan perkembangan fisik dan syaraf yang berada pada pusat syaraf. Sedangkan sosial emosiaonal mengarah kepada kemampuan bersoasialisasi serta mengendalikan emosi anak (Gunarti, 2014). Persepsi pola asuh permisif orang tua adalah suatu proses seorang anak untuk mengetahui, menginterpretasikan, dan mengevaluasi pola asuh permisif orang tua yang memberikan kebebasan sepenuhnya pada anak, tentang sifat-sifatnya dan keadaan yang lain yang ada dalam diri orang tua, sehingga terbentuk gambaran mengenai pola asuh permisif orang tua (Pravitasari, 2012). (Maulana, 2016) pola asuh yang diterapkan orang tua pada siswa akan berbeda sebab orang tua mempertimbangan kebutuhan siswa yang juga berbeda-beda pada kondisi dan situasi tertentu.

Anak dikatakan mengalami perlambatan perkembangan jika dua atau lebih kemampuan dasar ini tidak mampu berkembang secara optimal (Ngurah, dkk, 2008 dalam Gunarti, 2014). Tumbuh kembang optimal dapat tercapai apabila ada interaksi antara anak dan orang tua, terutama peranan ibu sangat bermanfaat bagi proses perkembangan anak secara keseluruhan karena orang tua dapat segera mengenali kelainan proses perkembangan anaknya dan sedini mungkin memberikan stimulasi pada tumbuh kembang anak yang menyeluruh dalam aspek fisik, mental, koginitf, bahasa dan sosial emosional. Pengembangan kemampuann dasar anak sangat dipengaruhi oleh pola asuh orang tua atau keluarga yang dilakukan kepada anaknya, misalnya peraturan dan cara mendidik yang ketat sehingga anak merasa terkekang (Soetjiningsih, 1995).

Menurut Hurlock (1990) pola asuh orang tua dibedakan menjadi tiga yaitu pola asuh otoriter, pola asuh permissif dan pola asuh demokratis. Pola asuh otoriter adalah orang tua yang mendidik anak dengan memperlihatkan ciri-ciri sebagai berikut: orang tua menerapkan peraturan yang ketat, tidak adanya kesempatan untuk mengemukakan pendapat, anak harus mematuhi segala peraturan yang dibuat oleh orang tua, berorientasi pada hukuman (fisik maupun verbal), dan orang tua jarang memberikan hadiah ataupun pujian. Pola asuh permissif memperlihatkan ciri-ciri sebagai berikut: orang tua cenderung memberikan kebebasan penuh pada anak tanpa ada batasan dan aturan dari orang tua, tidak adanya hadiah ataupun pujian meski anak berperilaku sosial baik, tidak adanya hukuman meski anak melanggar peraturan. Menurut Fitriana (2018) pola asuh orang tua yang otoriter yang selalu memberikan aturanaturan ketat terhadap anak, sering kali memaksa anak untuk berperilaku seperti dirinya dan selalu membatasi apapun yang dilakukan oleh anak sehingga anak akan mempunyai sifat ragu-ragu, tidak percaya diri, dan tidak sanggup mengambil keputusan sendiri. Menurut (Fahrizal, 2014) pola asuh permisif, yaitu pola asuh yang menerapkan kebebasan. Dalam pola asuh ini anak berhak menentukan apa yang akan ia lakukan dan orang tua memberikan fasilitas sesuai kemauan anak. Pola asuh demokratis memperlihatkan ciri-ciri adanya kesempatan anak untuk berpendapat mengapa ia melanggar peraturan sebelum hukuman dijatuhkan, hukuman diberikan kepada perilaku salah, dan memberi pujian ataupun hadiah kepada perilaku yang benar. (Vinayastri, 2015) pengaruh pola asuh (parenting) orang tua dalam perkembangan otak anak terutama selama 1000 hari pertama dalam kehidupan anak.

Pada anak usia dini kolaborasi antara pengasuhan dan pendikan di jenjang pendidikan anak usia menjadi faktor penentu keberhasilan stimulisasi perkembangan anak. Taman Kanak Kanak (TK) adalah salah satu bentuk penyelenggaraan pendidikan PAUD yang menitikberatkan pada peletakan dasar ke arah pertumbuhan dan perkembangan fisik (koordinasi motorik halus dan kasar), kecerdasan (daya pikir, daya cipta, kecerdasan emosi, kecerdasan spiritual), sosio emosional (sikap dan perilaku serta agama) bahasa dan komunikasi, sesuai dengan keunikan dan tahap-tahap perkembangan yang dilalui oleh anak usia dini.

Beberapa penelitian yang telah dilakukan menunjukkan adanya hubungan antara pola asuh terhadap perkembangan anak. Penelitian yang dilakukan oleh Fatimah (2011), menunjukkan terdapat hubungan antara pola asuh orang tua terhadap perkembangan anak di R A Darusalam, Desa Sumber Mulyo, Jogoroto, Jombang dengan nilai signifikansi sebesar 0,002 atau $\mathrm{P}<0,05$. Penelitian yang dilakukan oleh Dewi dan Pujiastuti (2012) menunjukkan adanya hubungan antara pola asuh orang tua terhadap perkembangan anak usia pra sekolah TK Kartika X-9 cimahi dengan nilai signifikansi sebesar 0,0013 atau $\mathrm{P}<0,05$. Berdasarkan uraian latar belakang tersebut dirasa relevan untuk melakukan penelitian terkait dengan hubungan pola asuh orang tua dengan perkembangan anak usia dini. Peneliti ingin mengetahui hubungan antara ketiga jenis pola asuh (otoriter, demokratis dan permissif) terhadap perkembangan anak usia dini. Adapun tujuan dalam penelitian ini adalah untuk mengetahui apakah pola asuh otoriter, demokratis dan permisif secara bersama-sama menunjukkan adanya hubungan dengan perkembangan nilai moral agama, sosial emosional, bahasa, kognitif dan fisik motorik. 


\section{Metode}

Penelitian ini termasuk tipe penelitian ex post facto, yaitu suatu penelitian empiris dan sistematis, dimana peneliti tidak melakukan pengendalian (kontrol) terhadap variabel bebas secara langsung, karena perwujudan variabel tersebut pada dasarnya tidak dapat dimanipulasi. Kesimpulan tentang hubungan antara variabel-variabel tersebut dibuat tanpa intervensi langsung berdasarkan perbedaan yang mengiringi variabel bebasdan variabel terikat tersebut.

Penelitian ini terdiri dari dua variabel, yaitu; pola asuh orang tua (tipe demokratis, otoriter dan permissif $(\mathrm{X} 1, \mathrm{X} 2, \mathrm{X} 3)$ merupakan variabel bebas dan perkembangan anak (Y) merupakan variabel terikat. Variabel terikat dalam penelitian ini terdiri dari perkembangan nilai moral dan agama (Y1), perkembangan sosial emosional (Y2), perkembangan bahasa (Y3), perkembangan kognitif (Y4), perkembangan fisik (Y5). Rancangan dalam penelitian ini adalah rancangan penelitian korelasional yang bertujuan untuk mengetahui ada tidaknya hubungan dua variabel atau lebih. Rancangan penelitian ini adalah sebagai berikut:

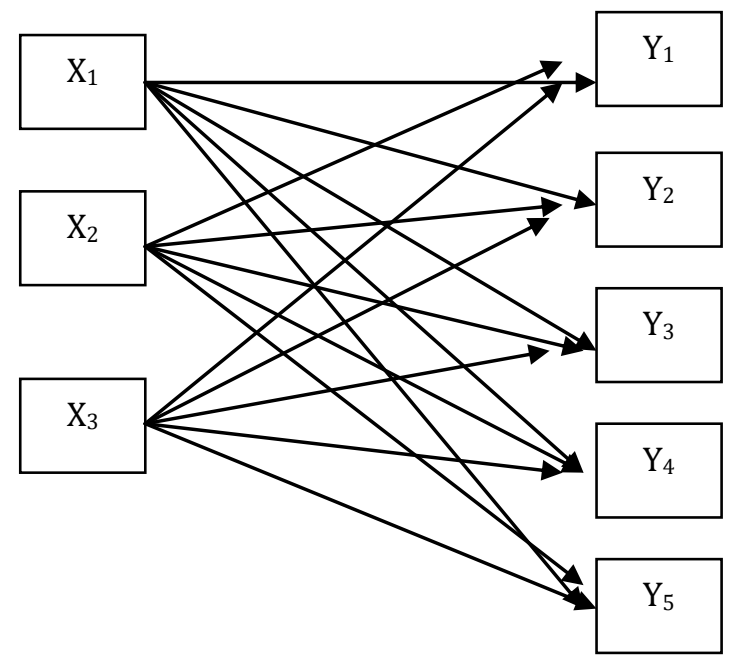

Instrumen dalam penelitian ini berupa angket pola asuh. Pengukuran instrument yang digunakan dalam penelitian ini yaitu skala likert dengan empat skala, Sangat Sesuai (SS), Sesuai (S), Tidak Sesuai (TS), dan Sangat Tidak Sesuai (STS). Pilihan jawaban sangat sesuai atau sesuai dipilih apabila dalam keseharian penerapan pola asuh yang dilakukan sangat sesuai atau sesuai dengan pernyataan yang disediakan oleh peneliti, sedangkan apabila pernyataan tidak sesuai dengan penerapan pola asuh yang diterapkan dalam keseharian, maka dapat dipilih jawaban yang tidak sesuai atau sangat tidak sesuai.

Skala yang digunakan dalam penelitian ini terdiri item unfavourable dan item favourable. Item favourable, jawaban sangat tidak sesuai diberikan skor 1, sedangkan jawaban sangat sesuai diberikan skor 4. Item unfavourable, jawaban sangat tidak sesuai diberikan skor 4, sedangkan jawaban sangat sesuai diberikan skor 1. Pernyataan favourable merupakan pernyataan yang berisi hal-hal yang positif atau mendukung terhadap obyek sikap. Pernyataan unfavourable merupakan pernyataan yang berisi hal-hal yang negatif yakni tidak mendukung atau kontra terhadap obyek sikap yang hendak diungkap.

Tabel 1. Kategori Respon

\begin{tabular}{llcc}
\hline No & \multicolumn{1}{c}{ Kategori } & Favourable & Unfavourable \\
\hline 1 & Sangat Sesuai (SS) & 4 & 1 \\
2 & Sesuai (S) & 3 & 2 \\
3 & Tidak Sesuai (TS) & 2 & 3 \\
4 & Sangat Tidak Sesuai (STS) & 1 & 4 \\
\hline
\end{tabular}

Sebelum instrument disusun menjadi item-item instrument, untuk memudahkan penyusunan instrument maka dibuat kisi-kisi instrument seperti yang ditunjukkan pada Tabel 2 dibawah ini. 
Tabel 2. Kisi-Kisi Instrumen

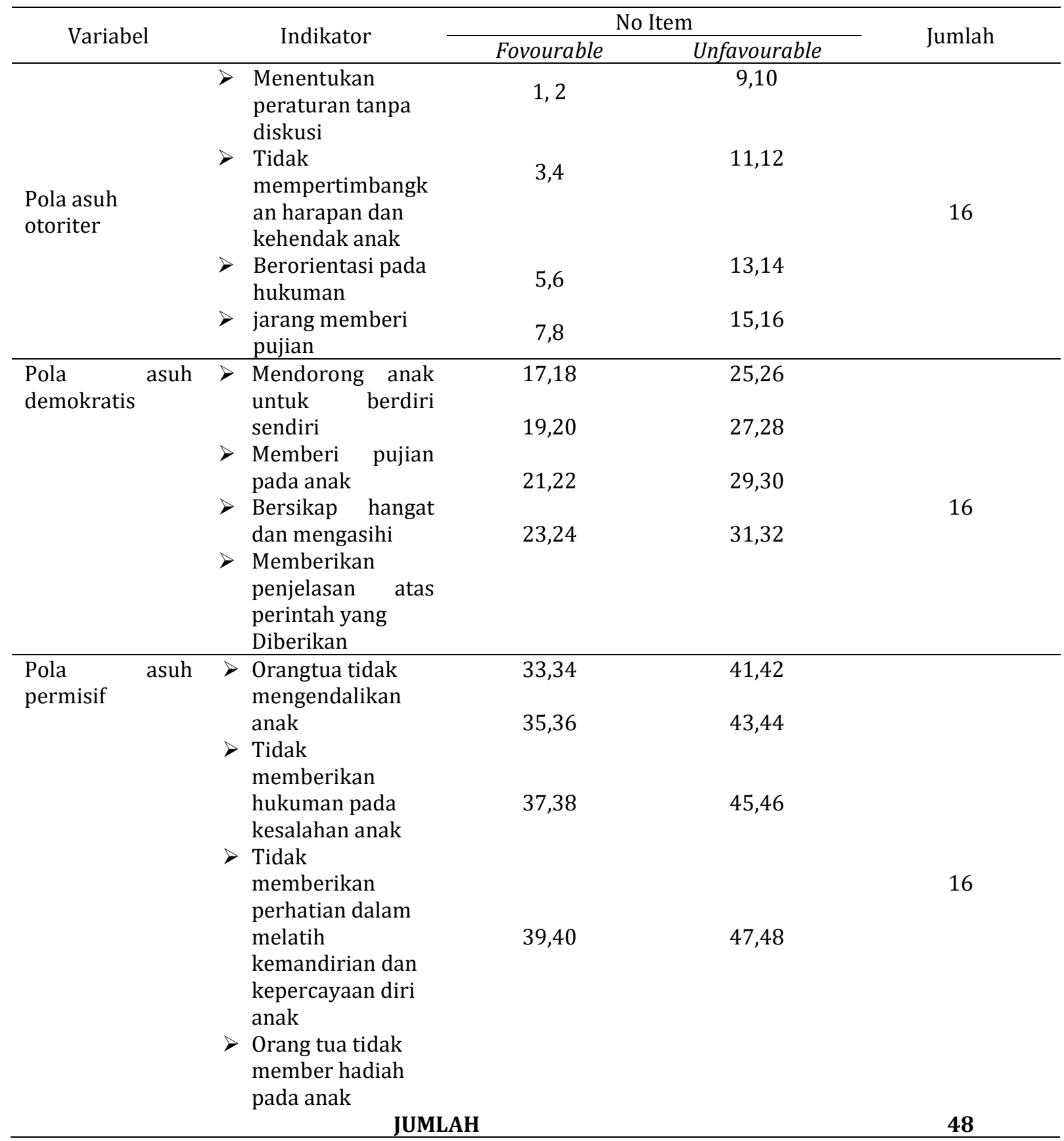

Instrumen yang dibuat sebelum digunakan dilakukan uji validitas dan reabilitas kuisioner pola asuh. Teknik analisis data penelitian ini menggunakan teknik analisis kanonik.

\section{Hasil dan Pembahasan}

Menurut Anzwar (2003) validitas butir kuesioner dihitung menggunakan korelasi Pearson Product, kriteria butir skala dalam kategori valid jika > , pada taraf signifikansi 0,05. Hasil uji validitas kuisioner menunjukkan dari 48 kuisioner seluruhnya berada pada kriteri valid. Reliabilitas kuesioner penelitian dihitung dengan rumus koefisien (Anzwar, 2003), reliabilitas instrumen dihitung hanya untuk butir-butir yang dinyatakan valid. Dari hasil perhitungan didapatkan nilai reliabilitas kuisioner pola asuh sebesar 0,7, ini artinya kuisioner penelitian berada pada derajat reliabilitas tinggi

Sebelum pengolahan data dengan korelasi kanonikal dimulai, diuji terlebih dahulu persyaratanpersyaratan yang harus dipenuhi yaitu normalitas, linearitas, dan multikolinear. Dari pengujian statistika dengan bantuan SPSS 16 for windows didapatkan secara umum semua data berdistribusi normal hal ini 
dapat dilihat dari nilai signifikansi yang lebih besar dari 0,05 pada uji Sphiro-Wilk. Berdasarkan hasil perhitungan Linieritas semua pasangan variabel terikat dengan variabel bebas memiliki nilai ANAVA dengan signifikansi > dari 0,05, hal ini berarti semua variabel linier.

Pengujian multikolinear dilakukan dengan mengkorelasikan diantara anggota kelompok variabel dependen dan diantara variabel independen. Berdasarkan hasil perhitungan diasumsikan antar variabel dalam kelompok tidak ada korelasi atau korelasinya 0, asumsi ini dilakukan agar dapat mempergunakan perhitungan korelasi kanonikal. Berdasarkan hasil perhitungan nilai VIF mendekati 1 untuk semua variabel bebas. Demikian pula, nilai tolerance mendekati 1 untuk semua variabel bebas. Dengan demikian, dapat disimpulkan bahwa dalam regresi antara variabel bebas pola asuh otoriter, demokratis, dan permisif terhadap perkembangan nilai moral agama, sosial emosional, bahasa, konitif dan fisik motorik tidak terjadi multikolinieritas antar variabel bebas.

Tabel 3. Perhitungan Penentuan Fungsi Kanonikal

\begin{tabular}{ccccccc}
\hline \multicolumn{8}{c}{ Eigenvalues and Canonical Correlations } \\
Root No. & Eigenvalue & Pct. & Cum. Pct. & Canon Cor. & Sq. Cor \\
\hline 1 & .58316 & 79.34352 & 79.34352 & .60692 & .36835 \\
2 & .09115 & 12.40193 & 91.74545 & .28903 & .08354 \\
3 & .06067 & 8.25455 & 100.00000 & .23916 & .05720 \\
\hline
\end{tabular}

\begin{tabular}{cccccc}
\hline \multicolumn{6}{c}{ Dimension Reduction Analysis } \\
Roots & Wilks L. & F & Hypoth. DF & Error DF & Sig. of F \\
\hline 1 T0 3 & .54577 & 1.54134 & 15.00 & 94.26 & .0106 \\
2 TO 3 & .86404 & .66327 & 8.00 & 70.00 & .0122 \\
3 T0 3 & .94280 & .72803 & 3.00 & 36.00 & .542 \\
\hline
\end{tabular}

Tabel 4. Tabel Perhitungan Secara Bersama

\begin{tabular}{lccccc}
\hline \multicolumn{6}{c}{ Multivariate Tests of Significance $(\mathrm{S}=3, \mathrm{M}=1 / 2, \mathrm{~N}=16)$} \\
\hline Test Name & Value & Approx. F & Hypoth. DF & Error DF & Sig. of F \\
& & & & & \\
Pillais & .50909 & 1.47152 & 15.00 & 108.00 & .0129 \\
Hotellings & .73498 & 1.60062 & 15.00 & 98.00 & .0087 \\
Wilks & .54577 & 1.54134 & 15.00 & 94.26 & .0106 \\
\hline \multicolumn{7}{c}{ Roys } & .36835 \\
\hline
\end{tabular}

Dengan menggunakan empat prosedur dari Pillais, Hotellings, Wilks, dan Roys, semuanya signifikan karena $<0,05$. Dengan demikian jika digabung secara bersama-sama, kanonikal fungsi 1 , kanonikal fungsi 2, dan kanonikal fungsi 3 sehingga dapat diproses lebih lanjut. Dengan melihat root ada tiga kanonik fungsi yaitu fungsi 1 korelasi kanonik 0,60692 dengan signifikansi 0,0106, fungsi 2 korelasi kanonik 0,28903 dengan signifikansi 0,0122, fungsi 3 korelasi kanonik 0,23916 dengan signifikansi 0,542. Oleh karena fungsi 1 memiliki angka korelasi kanonik yang tinggi dan signifikan baik secara individu maupun kolektif, maka analisis selanjutnya hanya menitik beratkan pada fungsi 1. (a)Interpretasi Kanonikal Variates, Analisis ini merupakan kelanjutan dari pengujian sebelumnya yang menetapkan kanonik fungsi 1, oleh karena itu dalam analisis ini hanya memperhatikan kanonikal fungsi 1 tidak meperhatikan fungsi 2 dan fungsi 3. Dalam penelitian ini ada dua kanonik variates yaitu dependen kanonik variates yang berisi perkembangan nilai moral agama, sosial emosional, bahasa, kognitif dan fisik motorik dan kanonik independenvariates yang berisi pola asuh otoriter, demokratis, dan permisif. Analisis ini berfungsi untuk mengetahui apakah semua variabel independen dalam kanonik variates berhubungan dengan dependen variates, yang diukur dengan besaran korelasi masing-masing independen variabel dengan variatnya. Pengukuran dilakukan dengan dua cara yaitu kanonikal Weights dan kanonikal Loadings. 
Tabel 5. Hasil Perhitungan Kanonikal Weights untuk Dependen Variabel

Standardized canonical coefficients for DEPENDENT variables

Function No.

\begin{tabular}{cccc}
\hline Variable & 1 & 2 & 3 \\
agama & .29045 & .94178 & .01235 \\
sosem & .29358 & -.31297 & .05276 \\
bahasa & .38501 & .07608 & 1.05974 \\
kognitif & -.02853 & .05655 & -1.28970 \\
fismot & .43612 & -.75342 & -.26219 \\
\hline
\end{tabular}

Tabel 6. Hasil Perhitungan Kanonikal Weights Untuk Independen Variat

\begin{tabular}{cccc}
\hline \multicolumn{5}{c}{ Raw canonical coefficients for COVARIATES } \\
Function No. \\
\hline COVARIATE & 1 & 2 & 3 \\
otoriter & -.04309 & -.09174 & .18338 \\
demokratis & .09799 & -.00600 & .01365 \\
permisif & .01531 & .05384 & .05453 \\
\hline
\end{tabular}

Dengan tidak memperhatikan fungsi 2 dan fungsi 3, terlihat deretan angka korelasi antara masingmasing variabelnya dengan variatnya. Untuk variabel dependen ada satu angka korelasi yang tinggi yaitu 0,43612 (perkembangan fisik motorik). Sedangkan untuk variabel independen ada satu angka korelasi yang tinggi yaitu 0,09799 (demokratis). Selain dengan kanonikal weights, interpretasi dilakukan dengan melihat besaran kanonikal loading.

Tabel 7. Hasil Perhitungan Kanonikal Loading Untuk Dependen Variat

\begin{tabular}{cccc}
\hline \multicolumn{5}{c}{ Correlations between DEPENDENT and canonical variables } \\
Function No. \\
\hline Variable & 1 & 2 & 3 \\
agama & .69231 & .63811 & -.08356 \\
sosem & .69516 & -.08061 & -.12268 \\
bahasa & .79492 & .12554 & .20076 \\
kognitif & .54637 & .20119 & -.60032 \\
fismot & .69791 & -.46838 & -.07828 \\
\hline
\end{tabular}

Tabel 8. Hasil Perhitungan Kanonikal Loading Untuk Independen Variat

Correlations between COVARIATES and canonical variables

CAN. VAR.

\begin{tabular}{cccc}
\hline Covariate & 1 & 2 & 3 \\
otoriter & -.14156 & -.68428 & .71535 \\
demokrat & .94324 & -.32698 & .05807 \\
permisif & -.00728 & .89499 & .44602 \\
\hline
\end{tabular}

Pada tabel 07 dan 08 hasil perhitungan kanonikal loading dengan hanya melihat fungsi 1 maka terlihat deretan angka korelasi loading masing-masing variabel dengan variabel variatnya. Untuk dependen variabel, ada dua angka kanonikal loading yang tinggi yaitu 0,79492 (bahasa) dan 0,69791 (fisik motorik). Sedangkan pada variabel independen ada dua kanonikal loading yaitu 0,94324 (demokratis) dan 0,14156 (otoriter). Berdasarkan hasil perhitungan diatas, maka diperoleh hasil sebagai berikut: 1) dua variabel dependent dan variabel independen memiliki hubungan yang signifikan. Dengan perkataan lain terdapat hubungan antara pola asuh otoriter, demokratis, dan permsisif dengan perkembangan nilai moral, sosial emosional, bahasa, kognitif, dan fisik motorik jika dilakukan pengujian secara kelompok, 2) dari tiga variabel independen, ada satu variabel yang memiliki hubungan yang sangat tinggi yaitu pola asuh demokratis. Dengan demikian dapat diartikan pola asuh demokratis berpengaruh terhadap perkembangan moral agama, soasial emosional, bahasa, kognitif, dan fisik motorik. 
Berdasarkan hasil pengolahan data secara kelompok ternyata menunjukkan hasil ada hubungan yang berarti antara pola asuh otoriter, demokratis dan permisif dengan perkembangan nilaia moral agama, sosial emosional, bahasa, kognitif dan fisik motorik. Walaupun secara individual tidak semua memiliki hubungan yang erat. Apabila diperhatikan hubungan antara kelompok variabel independen dengan kelompok variabel dependen menunjukkan adanya keterkaitan. Hal sesuai dengan beberapa teori yang telah dikemukan pada kajian teori bahwa perkembangan anak dipengaruhi oleh faktor pola asuh orang tua. Dari hasil penelitian ini didapatkan pola asuh yang paling tinggi memberikan pengaruh kepada perkembangan anak adalah pola asuh demokratis. Hasil penelitian sejalan dengan penelitian yang dilakukan oleh Amelia, Esa (2014) \& Krisdiyanto, Endra, dkk (2013, yang menyatakan pola asuh berpengaruh terhadap perkembangan anak usia dini.

Pola asuh otoriter adalah cara mengasuh anak yang dilakukan orang tua dengan menentukan sendiri aturan-aturan dan batasan-batasan yang mutlak harus ditaati oleh anak tanpa kompromi dan memperhitungkan keadaan anak. Serta orang tualah yang berkuasa menentukan segala sesuatu untuk anak dan anak hanyalah sebagai objek pelaksana saja. Jika anak-anaknya menentang atau membantah, maka ia tak segan-segan memberikan hukuman. Jadi, dalam hal ini kebebasan anak sangatlah dibatasi. Apa saja yang dilakukan anak harus sesuai dengan keinginan orang tua. Pada pola asuhan ini akan terjadi komunikasi satu arah. Orang tualah yang memberikan tugas dan menentukan berbagai aturan tanpa memperhitungkan keadaan dan keinginan anak. Perintah yang diberikan berorientasi pada sikap keras orang tua. Karena menurutnya tanpa sikap keras tersebut anak tidak akan melaksanakan tugas dan kewajibannya. Jadi anak melakukan perintah orang tua karena takut, bukan karena suatu kesadaran bahwa apa yang dikerjakannya itu akan bermanfaat bagi kehidupannya kelak (Parsono, 1994). Sedangkan pola asuh permisif anak dipandang sebagai makhluk hidup yang berpribadi bebas. Anak adalah subjek yang dapat bertindak dan berbuat menurut hati nuraninya. Orang tua membiarkan anaknya mencari dan menentukan sendiri apa yang diinginkannya. Kebebasan sepenuhnya diberikan kepada anak. Orang tua seperti ini cenderung kurang perhatian dan acuh tak acuh terhadap anaknya.

Hasil penelitian ini menunjukan diantara pola asuh otoriter, demokratis dan permisif, pola asuh demokratis mencerminkan hubungan yang sangat tinggi terhadap semua aspek perkembangan anak, jika dibandingkan dengan pola asuh otoriter dan pola asuh permisif. Dengan kata lain pola asuh demokratis memiliki pengaruh paling besar terhadap aspek perkembangan anak baik itu perkembangan nilai moral, sosial emosional, bahasa, kognitif dan fisik motorik.

Menurut Utami Munandar (1982 dalam Singgih, 1995) "Pola asuh demokratis adalah cara mendidik anak, di mana orang tua menentukan peraturan-peraturan tetapi dengan memperhatikan keadaan dan kebutuhan anak". Pola asuh demokratis adalah suatu bentuk pola asuh yang memperhatikan dan menghargai kebebasan anak, namun kebebasan itu tidak mutlak dan dengan bimbingan yang penuh pengertian antara orang tua dan anak (Singgih, 1995). Dengan kata lain, pola asuh demokratis ini memberikan kebebasan kepada anak untuk mengemukakan pendapat, melakukan apa yang diinginkannya dengan tidak melewati batas-batas atau aturanaturan yang telah ditetapkan orang tua. Orang tua juga selalu memberikan bimbingan dan arahan dengan penuh pengertian terhadap anak mana yang boleh dilakukan dan mana yang tidak. Hal tersebut dilakukan orang tua dengan lemah lembut dan penuh kasih sayang. Dengan penuh kasih sayang dan menghargai kebebasan anak sangat berpengaruh kepada perkembangan anak.

\section{Simpulan dan Saran}

Berdasarkan hasil analisis data, maka dapat disimpulkan sebagai berikut: (1) dua variabel dependent dan variabel independen memiliki hubungan yang signifikan. Dengan perkataan lain terdapat hubungan antara pola asuh otoriter, demokratis, dan permsisif dengan perkembangan nilai moral, sosial emosional, bahasa, kognitif, dan fisik motorik jika dilakukan pengujian secara kelompok, (2) dari tiga variabel independen, ada satu variabel yang memiliki hubungan yang sangat tinggi yaitu pola asuh demokratis. Dengan demikian dapat diartikan pola asuh demokratis berpengaruh terhadap perkembangan moral agama, soasial emosional, bahasa, kognitif, dan fisik motorik.

\section{Daftar Rujukan}

Anzwar. 2003. Reliabilitas dan Validitas. Yogyakarta: Liberty.

Amelia, Esa. 2014. Hubungan Pola Asuh Orangtua Dengan Perkembangan Sosial Dan Bahasa Anak Di Paud Aisyiyah Nur'aini Ngampilan Yogyakarta. Yogyakarta: Universitas Muhamadiyah. 
Andrade, dkk. 2005. Family environmental and child's cognitive development: an epidemiological approach. UFBa Rua Padre Feijo, 294 andar, hal: 2

Blair, C \& Diamond, A. 2008. Biological Processes in prevention and intervention: The Promotion of selfregulation as means of preventing school failure. Develompent and Psyhopatology. Vol 20:h 899-911

Danny I Y T. 1991. Kepribadian Keluarga Narkotika. Jakarta: Arcan.

Dewi \& Pujiastuti. 2012. Hubungan Pola Asuh Dengan Perkembangan Anak Usia Pra Sekolah di TK Kartika X-9 Cimahi 2012. Cimahi: STIKES Jendral Sudirman.

Djiwandono \& Sri E W. 2008. Psikologi Pendidikan. Cetakan Keempat. Jakarta: PT Grasindo.

Edward D C. 2006. Ketika Anak Sulit Diasuh: Panduan Orang Tua Mengubah Masalah Perilaku Anak. Bandung: PT Mizan Pustaka.

Elizabeth B. Hurlock 1990. Perkembangan Anak/Child Development, Terj. Meitasari Tjandrasa. Jakarta : Erlangga.

Fatimah, Listriana. 2012. Hubungan Pola Asuh Orang Tua dengan Perkembangan Anak di R.A Darussalam Desa Sumber Mulyo, Jogoroto, Jombang. Jombang: FIK UNIPDU Jombang.

Gunarti, dkk. 2014. Metode Pengembangan Perilaku dan Anak Usia Dini. Banten: Universitas Terbuka.

Krisdiyanto, Endra, dkk. 2013. Hubungan Pola Asuh Orang Tua Terhadap Perkembangan Motorik Anak Usia 3-5 Tahun. Semarang: STIKES Telogorojo.

Singgih D. Gunarsa. 1995. Psikologi Keperawatan. Jakarta: PP BPK Gunung Mulia.

Soetjiningsih. 2005. Tumbuh Kembang Anak. Jakarta: EGC.

Somantri, T. S. 2006. Psikologi Anak Luar Biasa. Bandung: PT Refika Aditama.

Suryaningsih, Ni Made Ayu. 2016. Implementasi Pembelajaran Inkuiri Terbimbing Berbasis Permainan Dalam Meningkatkan Kreativitas Anak Usia Dini. Jurnal Pendidikan Indonesia Vol. 5, No. 2, Oktober 2016

Fahrizal, E. (2014). Pengaruh Pola Asuh Orang Tua Terhadap Kemandirian Dalam Belajar Siswa. Jurnal Ilmiah Pendidikan Bimbingan Dan Konseling, (9220665), 50-59.

Fatimah, L. (2012). Hubungan Pola Asuh Orang Tua dengan Perkembangan Anak di R.A Darussalam Desa Sumber Mulyo, Jogoroto, Jombang. Prosiding Seminas, 1(2), 6.

Israfil. (2015). Hubungan Pola Asuh Orang Tua Dengan Perkembangan Anak Usia Prasekolah. Psychology Forum UMM, 175-179.

Novika Maulana. (2016). Pengaruh pola asuh dan komunikasi orang tua terhadap sikap sosial siswa kelas atas sd muhammadiyah baturan tahun ajaran 2015/2016, 1-11.

Pravitasari, T. (2012). Pengaruh persepsi pola asuh permisif orang tua terhadap perilaku membolos. Educational Psychology Journal, 1(1), 1-8.

Santosa, A. W. . dan A. M. (2013). Perbedaan Kemandirian Berdasarkan Tipe Pola Asuh Orang Tua pada Siswa SMP Negeri di Denpasar. Jurnal Fakultas Kedokteran. Universitas Udayana, 1(1), 54-62. Retrieved from https://ojs.unud.ac.id/index.php/psikologi/article/view/25048

Siswa, P., Negeri, S. M. A., Jambi, K., Siswa, P., Negeri, S. M. A., \& Jambi, K. (2013). No Title.

Vinayastri, A. (2015). Perkembangan Otak Anak Usia Dini. Jurnal Ilmiah WIDYA, 3(1), 33-42.

Yuniartiningtyas, F. (2012). Kepribadian Dengan Perilaku Bullying Di Sekolah Pada. Hubungan Antara Pola Asuh Orang Tua Dan Tipe Kepribadian Dengan Perilaku Bullying Di Sekolah Pada Siswa Smp, (1), 119. 